\title{
“It Could Have Been Said!”-On the Dialogical Space Between Machery and Deleuze ${ }^{*}$
}

\author{
Billy Bin Feng Huang \\ National Chengchi University, Taiwan, R.O.C.; Shilin High School of Commerce, Taiwan, R.O.C.
}

While I was teaching her the Water-Shedding Swordplay, I embedded four weaknesses in the routines.

(Reign of Assassins, 2010)

A philosophy...assumes that the notion of the virtual stops being vague and indeterminate.

(Deleuze, Bergsonism, 1991, p. 96)

This paper aims to parallelize the theorizations of Pierre Macherey and Gilles Deleuze. First, the author, according to Macherey, must have left something unsaid in his text. The unsaid or the narrative rupture is responsible for the multiplicity of the voices in the text, enabling the text to exist. Above all, Macherey argues that the unsaid or the narrative rupture emerges from how the author chooses to represent ideology. That is, Macherey's so-called unsaid or narrative rupture is actually what the author could have said; it is in fact a potentiality embedded in the text. On the other hand, when postulating his virtual(ity)/actual(ity) couplet, Deleuze asserts that the virtual(ity) is actually a potentiality that can be tapped. To be more precise, the virtual(ity) has its own reality, and once actualized, it will be transformed into something entirely new and different. Here, the dialogical space between Macherey and Deleuze is plain to see: Macherey's so-called unsaid or narrative rupture is literally Deleuze's so-called virtuality. When the unsaid is said, a virtuality is actualized. And a potentiality is thus tapped. By such a reading strategy, we readers are presented with an enactment of an alternative case scenario of the text, namely, how the text could have been made over. In the end, an example of this reading strategy is provided: Macherey argues that Marquis de Sade's desire-ruled society is more oppressive. What de Sade has left unsaid is the problematic relationship between desire and oppression. And it is exactly the potentiality in his works.

Keywords: Macherey, (un)said, narrative rupture, Deleuze, virtual(ity), actual(ity), potentiality

\footnotetext{
* Acknowledgements: This paper is adapted from my Ph.D. dissertation, "Say the Unsaid, Repair the Fractures-On the Narrative Ruptures in Edgar Alan Poe's Detective Stories”. Here, in addition to thanking the anonymous reviewer for his or her opinions on this paper, I would like to express my deepest appreciation for my Ph.D. dissertation advisors, Professor Frank W. Stevenson and Professor Eva Yin-I Chen. And I must also be thankful to Professor Chin-Yuan Hu, Professor Yi-Ping Liang, and Professor Brian D. Phillips, all three of whom participated in my oral defenses and proofread my Ph.D. dissertation.

Billy Bin Feng Huang, Ph.D. on English and American Literature of the English Department of National Chengchi University, Taiwan, R.O.C.; Senior English teacher of Shilin High School of Commerce, Taiwan, R.O.C.
} 


\section{Introduction}

Pierre Macherey (1938-) is a major French deconstructionist/Marxist. First, following a deconstructive line of thinking, Macherey throws extreme discredit on structure and focuses on the unsaid of a literary text. For Macherey, an author naturally leaves a lot of things unsaid, and the unsaid is precisely the reason why a literary text exists. In addition, the unsaid is tantamount to narrative ruptures, or the fractures beneath the surface of a seemly coherent structure in the literary text. Most of all, Macherey believes that the unsaid/narrative rupture is something inherent or embedded in the text. On the other hand, drawing on Hneri Bergson (1859-1941), Gilles Deleuze (1925-1995), the French post-modern philosopher, has put forward his notion of the virtual(ity) and actual(ity). (As the quote above indicates, Deleuze in Bergsonism has noticed that Bergson's philosophy has helped clarify his conceptions of the virtual(ity) and actual(ity).) In this paper, I aim to parallelize Macherey's so-called unsaid with Deleuze's so-called virtual(ity) and actual(ity). I shall demonstrate that this parallelization will open up the dialogical space between Macherey and Deleuze. Above all, by exploring this dialogical space, the Macheryan reading strategy shall be taken to a higher level.

\section{Macherey’s So-Called “Unsaid” or "Narrative Rupture”}

To fully grasp Macherey's conceptions of the narrative rupture or the unsaid, two fundamental questions must be answered: (1) How do we characterize the nature of the narrative rupture or the unsaid? (2) Where does the narrative rupture or the unsaid come from? Regarding the first question, we should note that the "unsaid" is a core concept in terms of a Machereyan reading. In A Theory of Literary Production, Macherey first states:

The speech of the book comes from a certain silence, a matter which it endows with form, a ground on which it traces a figure. Thus, the book is not self-sufficient; it is necessarily accompanied by a certain absence, without which it would not exist. A knowledge of the book must include a consideration of this absence. This is why it seems useful and legitimate to ask of every [literary] production what it tacitly implies, what it does not say...This moment of absence founds the speech of the work. Silences shape all speech. (1978, p. 85, italics mine)

For Macherey, the unsaid is the absence or silence that shapes the speech of the book. Above all, for the purpose of a fruitful reading, it is essential to look into the unsaid,

Speech eventually has nothing more to tell us: we investigate the silence, for it is this silence that is doing the speaking...it is this silence which tells us... which informs us of the precise conditions for the appearance of an utterance. (p. 86)

On the other hand, in emphasizing the importance of the unsaid, Macherey makes it clear that it "is not the same as the careless notation 'what it refuses to say'” but "what the work cannot say" (p. 87).

All in all, Macherey believes that the unsaid/silence/absence is the true essence of a literary work, and that any in-depth reading must originate from an investigation of it because it informs us of the prior condition in which the text is created. To expand on the meaning of "prior condition", Macherey quotes these "insidious questions” from Nietzsche's The Dawn of Day:

Insidious Questions: When we are confronted with any manifestation which someone has permitted us to see, we may ask: what is it meant to conceal? What is it meant to draw our attention from? What prejudice does it seek to raise? And again, how far does the subtlety of this dissimulation go? And in what respect is the man mistaken? (p. 87) 
As far as Macherey is concerned, these questions are "insidious" because they reveal an inconvenient truth: When producing a text, the writer puts in the contents only what (s)he allows us to see, which, at least in a way, may be seen as his or her prejudice. In the meantime, (s)he is also sure to conceal something; (s)he occasionally feels the need to divert our attention away from something. This is the general case scenario of a literary production. And Macherey concludes:

Therefore, everything happens as though the accent had been shifted: the work is revealed to itself and to others on two different levels: it makes visible, and it makes invisible...because attention is diverted from the very thing which is shown. This is the superposition of utterance and statement...: if the author does not always say what he states, he does not necessarily state what he says. (p. 88)

Here Macherey draws a distinction between the visible and the invisible in the text. The "visible" naturally refers to what the author has said or stated, namely, what is present in the contents of a text, while the "invisible", also known as "the unsaid", "the silence”, "the absence" "the margin”, or the "discontinuity" of a text (p. 90), indicates "the incompleteness" or the "actual decentered-ness" of a text (p. 79), the "diversity and multiplicity" or the "plurality of (its) voices of the text" (p. 26). In addition to differentiating the "visible" from the "invisible", Macherey draws another distinction between "the conscious" and the "unconscious" of the work. Doubtless, the former is "the said", or to be more exact, "what the work is compelled to say in order to say what it wants to say" (p. 94). The latter refers to a "latent knowledge" (p. 92), “the splitting”, the "division”, or "the reverse side of what is written" (p. 94), namely, the unsaid. Roughly speaking, the former is what the author has consciously said in the text, while the latter is what the author has left off in the text, which could be an unconscious act or a necessitated decision.

Based on the distinctions, Macherey posits his well-known "The Two Questions”: "First question: the work originates in a secret to be explained. Second question: the work is realized in the revelation of its secret” (p. 95). Needless to say, the first question aims at the theme the writer wishes to present, and the second question deals with the course of the writer's presentation of the theme. Macherey reminds us of the difference between them, "The simultaneity of the two questions defines a minute rupture, minutely distinct from a continuity. It is this rupture which must be studied” (p. 95). To put it simply, the theme the writer wants to present is always different from how the theme is actually presented; on the level of language, the true nature of the writer's linguistic utterance is always more complicated than it seems like on the surface. This is what Macherey calls "the narrative rupture” or the (narrative) “caesura” (p. 79). To illustrate the narrative rupture, Macherey gives us this schema (p. 87):

$\begin{array}{lll}\text { utterance } & \text { question } 2 \\ \text { question } 1 & \end{array}$

For Macherey, a literary utterance is equivalent to Question 1. As stated above, an utterance is potentially the writer's dissimulation. And an error could be committed if we stay exclusively focused on it:

We can then ask to what extent the first question was based on an error: because this dissimulation applies to everything it must not be thought that it is total and unlimited...So the real trap of language is its tacit positiveness which makes it into a truly active insistence: the error belongs as much with the one who reveals it as it does with the one who asks the first questions, the critic. (p. 89) 
This error is what Macherey calls "the real trap of language": On the surface language is a vehicle for revelation and expression, but in reality it could be dissimulative. In Macherey's opinion, both the writer and the critic ordinarily fall for it. To avoid erring as they do, we must ask Question 2 or explore the unsaid in the text. By so doing a critic will go for explanation rather than interpretation because the former perceives "the spontaneously deceptive character of the work” (p. 76):

The necessity of the work is founded on the multiplicity of its meanings: to explain the work is to recognize and differentiate the principle of this diversity...the work would be full of meaning, and it is this plenitude which must be examined...it measures the distance which separates the various meanings...we must stress that determinate insufficiency, that incompleteness which actually shapes the work. The work must be incomplete in itself... (pp. 78-79)

As for the latter:

Interpretation is repetition, but a strange repetition that says more by saying less: a purifying repetition, at the end of which a hidden meaning appears in all its naked truth. The work is only the expression of this meaning...The interpreter accomplishes this liberating violence: he dismantles the work in order to be able to reconstruct it in the image of its meaning, to make it denote directly what it had expressed obliquely...it presupposes the active presence of a single meaning around which the work is diversely articulated. (p. 76)

To put it simply, interpretation repulses Macherey because it merely concentrates on Question 1. If Question 2 has to be addressed, we must go for explanation. In addition, by exploring the unsaid, a critic will be aware of the necessity of examining "the work in its real complexity rather than its mythical depth" (p. 99). By "complexity", Macherey means that "the work, in order to say one thing, has at the same time to say another thing which is not necessarily of the same nature; it unites in a single text several different lines which cannot be apportioned...” (p. 99). Last but not least, an investigation of the unsaid will enable the critic to learn that:

the work has no interior, no exterior; or rather, its interior is like an exterior, shattered and on display. Thus, it is open to the searching gaze, peeled, disemboweled. It shows what it does not say by a sign which cannot be heard but must be seen...In particular, it must be realized that the work is not like an interior which is wholly congruent with an exterior: such an assumption is responsible for all the errors of casual explanation. (pp. 96-97)

For Macherey, the unsaid of the text basically consists in the discrepancy between its exterior and interior. The following analysis is definitely fallacious: "the work encloses the warm intimacy of its secrets, composes its elements into a totality which is sufficient, completed and centered...” (p. 96).

In formulating his theorizations, Macherey has created these pairs: the unsaid (unspoken) and the said (spoken), the invisible and visible, the unconscious and conscious, the explanation and interpretation, the complexity and depth, and the interior and exterior. And he uses a number of jargons, including the narrative rupture, the caesura, the absence, the silence, the incompleteness or decenteredness, the multiplicity or diversity, the discontinuity or margin...All these are meant to illuminate a crucial fact: A text is not what it seems like; underneath its thin textual surface are a multitude of unsaid things and narrative ruptures. In response to our first question in the beginning of this section, we may conclude that the narrative unsaid or rupture can be essentially defined as what the author chooses not to say in the text. It is paramount to note that Macherey's so-called “unsaid” or “narrative rupture” shouldn’t be viewed as weaknesses that have to be redressed (as the line quoted from the 2010 film Reign of Assassins); instead, it is a perfect point of departure in exploring the multiple meanings of the text. 
As for the second question, I will start with what Macherey thinks of Poe's "The Philosophy of Composition”. First of all, Macherey takes issue with Poe in terms of this essay, thinking it "has no theoretical value” (p. 23). However, he does agree on Poe’s claim “composition is construction” (p. 23):

Either history affords a thesis — or one is suggested by an incident of the day—or, at best, the author sets himself to work in the combination of striking events to form merely the basis of his narrative-designing, generally, to fill in with description, dialogue, or authorial comment, whatever crevices of fact, or action, may, from page to page, render themselves apparent. (p. 23)

On the basis of the quoted passage, Macherey believes that Poe aims "to refute the fallacies about spontaneous creativity...The spontaneity of the reader contrasts with the rational calculation of the author” (p. 23). That is, Poe thinks of every story as a construction; the author personally works certain fragments of reality into the narrative of the story, to which he adds various descriptions, dialogues, actions, or comments. To put it simply, a story has to originate from its external reality.

Such a point of view is a perfect point of departure for an insight into Macherety's so-called "narrative ruptures". Firstly, Macherey basically stands by this claim. As Mao Tse-Tung states, "Works of literature and art...are the product of the reflection in the human brain of the life of a given society” (1971, p. 250), Macherey also considers literature a reflection. However, he also asserts that "to reproduce all reality is obviously an unattainable...objective” (Macherey, \& Lanser, 1976, p. 6). To pursue this point, Macherey gives us two key words, "history/ (social) reality" and "ideology":

This history is not a simple external relation to the work: it is present in the work...This history...entirely determines the work....if [the author] chose to be the spokesman of a certain ideological condition...he expressed that choice. These are two different operations...These are two “choices;” the gap between them measures the absence within the work... (pp. 93-94, italics mine)

\section{Then Macherey goes on to argue:}

We know that a writer never reflects mechanically or rigorously the ideology which he represents even if his sole intention is to represent it: perhaps because no ideology is sufficiently consistent to survive the test of figuration...The writer always reveals or writes from a certain position...in relation to this ideological climate: he constructs a specific image of ideology which is not exactly identical with ideology as it is given, whether it betrays it, whether it puts it in question, or whether it modifies it. This is what must finally be taken into account in order to know what the work is made of. And the author does not always need to say what he is making. (p. 195)

When Macherey states that "the author does not always need to say what he is making”, he is referring to "the unsaid" or "the narrative ruptures" of the text. All in all, Macherey's main emphasis is that a text is always embedded in the history, where the author can choose to represent a certain ideological condition from a certain position. And it is the inaccuracy of the author's representation that results in the unsaid or the narrative ruptures. For Macherey, "it is impossible for a specific work to reproduce the totality of an ideology: a partial apprehension is all that possible” (p. 232). This is the answer to our second question: the unsaid or the narrative rupture originates from the author's incomplete representation of ideology from a specific stance. That's also why the unsaid things are embedded in the text, just as the text is embedded in history.

In "Literature as an Ideological Form", Balibar and Macherey further such an analysis by explicating the relationship between history, ideology, and literature. First, they take notice of the "intricate and connected 
relationship between history and literature”. Then they draw on Althusser’s concept of the ISA:

Ideological forms...are manifested through the workings and history of determinate practices in determinate social relations, what Althusser calls the Ideological State Apparatuses (ISA). The objectivity of literary production therefore is inseparable from given social practices in a given ISA...By connecting the objective existence of literature to this ensemble of practices, one can define the material anchoring points which make literature a historical and social reality. (1995, p. 280)

At last they conclude that "literature is historically constituted...in the dominant ideology” (p. 280). That is, ideology, formed in a particular historical reality, impinges directly on literary productions. However, "the basis of literary production is an unequal and contradictory relation to” the dominant ideology (p. 280). Here, Balibar and Macherey would like to draw our attention to the ideological contradictions:

To be more explicit: literature is produced finally through the effect of one or more ideological contradictions precisely because these contradictions cannot be solved within the ideology...literature "begins" with the imaginary solution of implacable ideological contradictions, with the representation of that solution... (p. 284)

This is what Balibar and Macherey term "the literary effect”: "an internal contradiction” in the text (p. 279). To be more specific, the text, "the ideological project of the author", or "the expression of one determinate class position", "is only one of the terms of the contradiction of whose oppositions the text makes an imaginary synthesis despite the real oppositions which it cannot abolish” (p. 284). On the surface, the text may seem to have incorporated these ideological contradictions, but actually, they remain unresolved and lead to the internal division of the text, namely, the unsaid or the narrative rupture ${ }^{1}$.

Here Macherey wants us to note that there are contradictions in a literary text because historical contradictions are not directly or adequately reflected in the text; in the text are nothing more than imaginary solutions to these contradictions. Macherey uses Leo Tolstoy's works to exemplify this point. First, he gives us this schema to illustrate the relationship between history and the text:

contradictions

in the book historical

deficiencies

\section{reflection}

in the mirror

"By means of contradictory images the mirror represents and evokes the historical contradictions of the period” (p. 126), Macherey states. Then he urges, "We must now identify these terms and find out which contradictions are involved” (p. 126), for Tolstoy’s works do not mirror these historical contradictions truthfully.

\footnotetext{
${ }^{1}$ As Balibar and Macherey speak of the literary effect, they have actually adopted a materialist perspective. For them, this term refers to a "material disparity" (p. 283). "Dialectically, literature is simultaneously a product and material condition of the linguistic division in education, term and effect of its own contradictions” (p. 282). It certainly reminds us of Raymond Williams' emphasis on materiality. In What I Came to Say, Williams starts with Karl Marx's categorical distinction of material and mental productive forces of culture. Then he argues that they both have "an inescapable material and thus social history". Paul Jones regards Williams' emphasis on cultural materiality as "his most explicit declaration of the conception of cultural productive forces that is quite crucial to his mature sociology of culture”. See Raymond Williams, What I Came to Say, ed. by Francis Mullhern (London: Hutchinson Radius, 1989), p. 211. Paul Jones, Raymond Williams' Sociology of Culture: A Critical Reconstruction (London: Macmillion, 2003), p. 19.
} 
To be more specific, these historical deficiencies are not reflected but transmuted into the contradictions in Tolstoy’s works. In this respect, Macherey gives us his observation:

The total historical structure...really determines Tolstoy's works only in so far as it enables to take account of his particular point of view. Tolstoy's personal point of view is determined by his social origin: Count Tolstoy spontaneously represents the landed aristocracy. But as a writer...he enjoys a certain social mobility: he has the status of a traveler. In his work, Tolstoy establishes a novel relationship to the history of his time by drawing on an ideology which is not "naturally" his own, by looking to the peasant. (pp. 113-114)

Macherey sees how Tolstoy's society was divided into the peasantry and the landed aristocracy. And such a division is refracted in Tolstoy's works because Tolstoy, a landed nobleman, decided to side with the peasantry. Thus, this refraction has transformed into two major contradictions in Tolstoy's works:

$\begin{array}{ll}\begin{array}{l}\text { 1. great artist } \\ \text { protest }\end{array} & \begin{array}{l}\text { landlord obsessed with Christ } \\ \text { quietism (in all its forms) }\end{array}\end{array}$

$\begin{array}{ll}\begin{array}{l}\text { 2. } \\ \text { realisism }\end{array} & \begin{array}{l}\text { non-violence } \\ \text { preaching }\end{array}\end{array}$

The schema above illustrates the two contradictions in Tolstoy's works, on which Macherey states:

The first contradiction relates Tolstoy's work...to Tolstoy's real situation...But this second term of the contradiction...implies the conflict between Tolstoy's natural situation (his relationship by birth to history) and his ideological situation, (which allows him to displace his relation to history)...Tolstoy has no other reason to change his relation to history except that of becoming a writer, and since his preaching remains essentially a preaching by means of books. (pp. 126-127)

In brief, Tolstoy's works ambivalently reflect the social division (contradiction) of Tolstoy's time: Tolstoy's works are replete with his non-violent but protesting preaching as well his sympathy with the Russian peasantry. However, if we take into account the fact that Tolstoy actually belongs to a social class supposedly antagonistic to the peasantry, we'll understand that it is literally a narrative rupture. While Tolstoy is expanding on his theme, he has also left the following unsaid: I (Tolstoy) am actually one of those to whom I've addressed my criticism; that is to say, I am straddling the gap between the landed aristocracy and the peasantry. To some extent, the unsaid/narrative rupture is the consequence of Tolstoy's ideological displacement in the social hierarchy.

Clearly, Macherey's reading strategy has influenced theorists such as Catherine Belsey. In Critical Practice, Belsey elaborates on the concept of "the interrogative text”, which, instead of "imparting 'knowledge' to a reader whose position is thereby stabilized”, "brings points of view into unresolved collision or contradiction” (1980, pp. 91-92 $)^{2}$. Doubtless, her concept bears striking similarity to Macherey’s narrative rupture. Another example is Andrew Bennett and Nicholas Royle, who discuss "the importance and value of aporia" in Introduction to

2 Belsey's Critical Practice also highlights the key notion of "plural meanings", which has a lot in common with Mikhail Bakhtin's "polyphonic" or "dialogic" novel, a term he uses to talk about a text with a multiplicity of equal voices. In Problems of Dostoevsky's Poetics, he states, "It is not a multitude of characters and fates within a unified, objective world, illuminated by the author's unified consciousness that unfolds in his works, but precisely the plurality of equal consciousnesses and their worlds, which are combined here in the unity of a given event, while at the same time retaining their unmergedness". Later in this book, Bakhtin concludes that “consciousness is essentially 'unfinalizable’”. See Mikhail Bakhtin, Problems of Dostoevsky's Poetics, trans. by R. W. Rostel (Michigan: Ardis/Ann Arbor, 1976), p. 4, pp. 55-56. 
Literature, Criticism and Theory (1999, p. 256). In the course of their discussion, they have highlighted a key word, "undecidability", which "dislodges the principle of a single final meaning in a literary text” (p. 195). On the other hand, Macherey's theorizations actually have a solid foundation of post-Marxism. For example, when Althusser proffers his concept of overdetermination, his main emphasis is that individuals as well as texts, because of their "relative autonomy of the superstructure", may well assume "multiple, unstable, and decentered identities” (Wolff, 2005, p. 227). It perfectly corresponds to Macherey’s argument that a text may have multiple meanings. Eagleton's influence on Macherey is more obvious: in Criticism and Ideology, Eagleton states, “The text puts the ideology into contradiction, discloses the limits and absences which mark its relation to history, and in doing so puts itself into question, producing a lack and disorder within itself” (1976, p. 95). That is, not only has Eagleton viewed the interrelationship of history, ideology, and literature the same way as Macherey, but also his so-called "lack and disorder" of the text literally equals to Machery's narrative rupture. What's more, Jameson, drawing on Lacanian psychoanalysis in The Political Unconscious, defines the text as "the symbolic act” (1981, p. 77), and compares History to the Real (p. 81) ${ }^{3}$. In this respect, Jameson has apparently found a literary and linguistic application for Lacan's view, “That is, interpretations combine language with experience to construct 'reality', but not the Real which remains beyond signification” (Boeckmann, 1998, p. 37). Therefore, what we have is a paradox: The text is both drawing the Real into itself and denying its existence simultaneously. Jameson believes that if a text can be characterized this way, then a social contradiction, in an ideological form, has to occur at a submerged or hidden level, and it can be reconstructed as a subtext. In other words, we can literally draw "the distinction between manifest and latent meaning written into the narrative" (Dowling, 1984, p. 98). Certainly, Jameson's “manifest and latent meaning” of the text is tantamount to Macherey's the said and the unsaid of the text ${ }^{4}$.

\section{From Macherey’s Unsaid to Deleuze's Virtual(ity) and Actual(ity) Model: The Dialogical Space}

In the previous section of this paper, I’ve made quite an effort to delve into Macherey's theorizations about the unsaid in the text. Now, it's time to explore the dialogical space between Macherey and Deleuze. Before I proceed any further, I feel the need to ask another two key questions: (1) Can Macherey's so-called unsaid be said? (2) What will happen if we say the unsaid? And I believe by answering the two questions, we can discover how Machery has been dialogically engaged with Deleuze. Before attempting to answer the first question, we must

\footnotetext{
3 To illustrate the concept of a symbolic act, Jameson, in The Political Unconscious, quotes Kenneth Burke, stating that Burke's so-called "dream", "prayer", or "chart" is a way of doing something to the world. It has to take up the contents of the world into itself in order to submit it to the transformations of form. In addition, Jameson's invokes the Lacanian and Freudian psychoanalytic models to theorize about his hermeneutics, which indicates that he has adopted a structuralist approach. Edith Kurzweil notices that a structuralist psychoanalyst always makes a "systematic attempt to uncover deep universal mental structures as these manifest themselves...in the unconscious psychological patterns that motivate human behavior”, Kurzwel's remarks, if contextualized politically, are consistent with Jameson's intention of Political Unconscious. See Jameson, 1981 , p. 81. Kenneth Burke, The Philosophy of Literary Form (Princeton: University of California Press, 1973), pp. 5-6. Edith Kurzweil, The Age of Structuralism: Levi-Strauss to Foucault (New York: Columbia University Press, 1980), p. 1.

4 The above is merely a summary of how Macherey's theorizations have intersected with post-Marxism. In my "Some Things Must Be Left Unsaid!”, I’ve conducted a detailed genealogical investigation of how Macherey is dialogically engaged with post-Marxism. And I've concluded that "a fruitful discussion of Macherey must include comparing him with the other prominent post-Marxists, such as Althusser, Eagleton, and Jameson”. See Billy Bin Feng Huang, “'Some Things Must Be Left Unsaid!'-On How Macherey Is Dialogically Engaged with Post-Marxism”, Journal of Literature and Art Studies, Vol. 8, No. 3 (2018), p. 507.
} 
realize that when Macherey states, “The speech of the book comes from a certain silence” (1978, p. 85), or that the incompleteness of the work "is the true reason for its composition" (p. 79), what he truly means is:

Thus, the silence of the book is not a lack to be remedied, an inadequacy to be made up for. It is not a temporary silence that could finally be abolished. We must distinguish the necessity of this silence. For example, it can be shown that it is the juxtaposition and conflict of several meanings which produces the radical otherness which shapes the work: this conflict it not resolved or absorbed, but simply displayed. (p. 84)

Macherey's primary emphasis here is what I've already clarified previously: a narrative rupture is not an error that has to be corrected or a weakness that needs to be redressed. Therefore, the radical otherness created by the unsaid should not be dissolved. Rather, it must exist in the work as a precondition for its composition. As for whether or not the unsaid can be said, Macherey gives us a considerably paradoxical statement in the following paragraph, "Thus, the work cannot speak of the more or less complex opposition which structures it; though it is its expression and embodiment” (p. 84). This statement, literally interpreted, seemly indicates that the unsaid in the text cannot be said, though the text itself depends on it.

However, if the unsaid couldn’t be said, if would be pointless for Macherey to ask "Question 2", which we've already talked about. (It would be equally pointless to invoke Jameson, now that he thinks whatever is repressed/unsaid can constitute the subtext waiting for us to explore.) Moreover, if Macherey denied the possibility that a narrative rupture could be repaired, why would he come up with such an utterance? "The work exists only because it is not exactly what it could have been, what it ought to have been” (p. 198). Clearly, Macherey believes that the existence of a text is one single case scenario (the said), while there are countless potential case scenarios that can be explored (the unsaid), as Macherey explains later, "it [the text] is born of...the impossibility of the work's filling the ideological frame for which it could have been made” (p. 198, italics mine). Here, Macherey's remarks are most intriguing: Macherey apparently equates the unsaid/narrative rupture with what a text could or should have been. If so, then his so-called unsaid may be a possibility, or an alternative direction the narrative could have moved in. From this point of view, it is no wonder that Macherey states that "the work cannot speak of the more or less complex opposition which structures it!” This is because the dice are cast! Since the text we've targeted is already written, there is no way that its author can rewrite it. Naturally, these possibilities are precluded for the text, and the text cannot say the unsaid. On the other hand, these possibilities remain open for us; we readers can say the unsaid or repair the narrative ruptures by putting ourselves in the author's shoes. This is how we can learn the alternative developments of the text. Hence, here is the answer to our first question: As far as the text is concerned, the unsaid cannot be said because what's done is done; however, from a readerly standpoint, the unsaid can and must be said if an in-depth reading of the text is desired.

If the unsaid is a possibility, we may very well consider it a potentiality. John Russo offers us a perfect example:

Imagine yourself wanting to write a story, or wanting to speak in class. In both cases, you have a strong feeling of what you want to express...Only in coming to words does your initial sense become something real—until it is articulated, it is only the promise of a meaning, but you have not yet actually said anything. And this sometimes happens: ...we have lost the thought; it never came to words...In the absence of articulation, the sense amounts to nothing. And yet, the "nothing" that it amounts to does not do it justice...or more exactly, there was a real potentiality for meaning there. When we do put it in words, that potentiality does for the first time become something actually meaningful... (2008, pp. 95-96) 
This long quoted passage of Russo gives us an insight into the nature of the unsaid: The unsaid is never articulated, so it is an unfulfilled promise of meaning. On the other hand, it is erroneous to view the unsaid as nothing because it is actually a potentiality that is waiting to be tapped. Andrew Gibson, in Towards a Postmodern Narratology, ascertains the materiality of writing by observing a repository of "others" suppressed in the narrative. Besides, according to him, writing is material simply because it can bring back whatever is excluded in the narratological conception of voice (1996, p. 168). If those that are suppressed or excluded can be brought back, in Russo's opinion they are just like potentialities to be tapped.

If Macherey's unsaid may be viewed as a potentiality, then his dialogical relationship with Deleuze is plain to see! In Difference and Repetition, Deleuze has postulated his virtual(ity)/actual(ity) couplet:

We opposed the virtual and the real: although it could not have been more precise before now, this terminology must be corrected. The virtual is opposed not to the real but to the actual. The virtual is fully real in so far as it is virtual. Exactly what Proust said of states of resonance must be said of the virtual: "Real without being actual, ideal without being abstract”; and symbolic without being fictional. (1995, p. 208)

First of all, as we've mentioned previously, the couplet of "virtual(ity) and actual(ity)" is a concept derived from Bergson's philosophy, and above all, in Deleuze's opinion, "there are different modes of being regarding the virtual” (Pearson, 1997, p. 1119) ${ }^{5}$. And it’s perhaps why Deleuze's remarks here are seemly puzzling; it seems that we can't make out what he really means, except merely telling that he explicitly pairs the virtual with the actual. Regarding Deleuze's enigmatic statements, "The virtual is fully real in so far as it is virtual" and the quote of Proust, "Real without being actual, ideal without being abstract", K. Ansell Pearson offers his explanation from a perspective of conceptual creation. He argues that concepts are not created out of "no-things" in the realm of the virtual; they still "do not conjure things out of thin air...Their compositions are only possible because they...tap into the virtual and immanent processes” (1997, p. 4). In a way, Ansell Pearson has viewed the virtual(ity) as a potentiality, which makes possible conceptual creation. This is what Deleuze means by "The virtual is fully real in so far as it is virtual". Steven Shaviro is more specific; he deciphers Deleuze's words in the following way, "The virtual is like a field of energies that have not yet been expended, or a reservoir of potentialities that have not yet been tapped” (2009, p. 34). As if following Ansell Pearson's line of thinking, Shaviron means to tell us: If the virtual can be positively identified as a potentiality to be tapped, then it is understandable why the virtual could be both real and ideal: The virtual is a dimension that has not yet become an actuality in the physical world; this dimension is very real because it has a reality of its own. On the other hand, just as a potentiality needs to be tapped and an ideal has to be fulfilled, the virtual must be actualized, just as

\footnotetext{
${ }^{5}$ For instance, in Matter and Memory, Bergson researches the virtuality of human recollection. He argues, "Whenever we are trying to recover a recollection, to call up some period of our history, we become conscious of an act sui generis by which we detach ourselves from the present in order to replace ourselves, first, in the past in general, then, in a certain region of the past-a work of adjustment like the focusing of a camera. But our recollection still remains virtual...” (pp. 133-134). In short, Bergson asserts that these recollections "provide a resistance to the present action" and "introduce into the minds certain new ways of feeling and thinking” (pp. 177, 151). On the other hand, Pearson points out, "For Deleuze it is pure recollection that is the plane of pure virtuality. This is what distinguishes the virtual image peculiar to memory”. Most of all, Deleuze has applied his theorizations about the virtuality of human memory to characterizing the nature of time in Cinema 2: The Time Image. He states that while recollections and dreams "are necessarily actualized in relation to a new present, in relation to a different present from theone that they have been", they cannot be defined simply in accordance with a new present in relation to which it would be past (pp. 79-80). See Henri Bergson, Matter and Memory. Trans. by. N. M. Paul \& W. Scott Palmer (New York: Zone Books, 1991), pp. 133-134, 151, 177. Gilles Deleuze, Cinema 2: The Time Image. Trans. by H. Tomlinson \& R. Galeta (London: Continuum Press, 1989), pp. 79-80. Pearson, 2005, p. 1120.
} 
Deleuze explains after the quoted passage, "By contrast, the virtual...possesses a full reality by itself. The process it undergoes is actualization” (p. 211).

At this point, I feel compelled to elaborate further on Deleuze's couplet of virtuality and actuality. Aside from Bergson, this Deleuzean concept is closely correlated to Kant. In "Deleuze's Concept of the Virtual and the Critique of the Possible”, Daniel W. Smith poses this question, "does Deleuze return to a more or less direct confrontation with Kant in Difference and Repetition (1968)?” (2009, p. 37). On the other hand, the answer to Smith's question may be found in Deleuze's "Response to a Question on the Subject”, in which he states that he has assigned many of the Kantian notions to new functions and variables, inserting them into a completely new field, to the extent where there is no a multiple field of the virtual (2006, p. 349) ${ }^{6}$. In short, Deleuze's couplet of virtuality and actuality is a result of his effort to rework a Kantian notion. But how does Deleuze do that? Smith has given us the answer:

In Kant, Ideas are unifying, totalizing, and conditioning; in Deleuze, they are differential, virtual, and genetic. They are neither universals nor constants, but rather multiplicities in constant variation... Though the virtual is not itself actual, it nonetheless possesses a reality that is completely determined by is elements, relations, singularites, and so on...the virtual is actualized by differentiating itself in variable directions. The differential relations are actualized in diverse spatio-temporal relationships, and the elements are incarnated in a variety of actual terms and forms. (p. 41)

Smith has given us a summary of how Deleuze has invested the couplet of virtual(ity) and actual(ity) with new meanings based on the Kantian tradition. First of all, Deleuze argues that ideas are fundamentally virtual because they are differential and variable in every respect. In addition, the virtual is not actual but still possesses a reality that is determined by differential relations. Last but not least, as Deleuze states in Bergsonism, "The characteristic of virtuality is to exist in such a way that it is actualized by being differentiated and is forced to differentiate itself, to create its lines of actualization, in order to be actualized" (1991, p. 97), the virtual is actualized on the condition that the former must be differentiated, namely, become something new. To be more precise, whenever a virtuality is actualized, the elements in its own reality must be transformed into the terms in its actual relationship with the material world ${ }^{7}$.

In What Is Philosophy?, Deleuze and Guattari use a term "a virtual image", which means something that must be "tailored to the thing itself, which only suits that thing, and which, in this sense, is no broader than what it must account for” (1994, p. 20). Len Lawlor gives Deleuze aand Guattari’s remarks a clear explanation, stating that virtual images are "pure presences" or "tendencies". They have the power to make alterations. Above all, what they create "does not correspond to or resemble reality. This disparity with the real is why the virtual image

\footnotetext{
${ }^{6}$ As a matter of fact, Deleuze's confrontation with Kant, according to Smith, is directly due to his opposition to Hegel, "[Here is] Deleuze's...strategy: rather than attacking Hegel directly, he instead returns to the very problematics that generated the post-Kantian tradition to which Hegel belongs, precisely in order to propose a different and divergent solution to those same problematics. But this is why, it seems to me...a direct confrontation of Deleuze with Kant was inevitable" (italics mine). See Smith, 2009, p. 37.

${ }^{7}$ In The Logic of Sense, Deleuze has argued that such a process could be regarded as a causality. He claims that aside from the actual, material connections of physical causes to one another, there is a virtual relation or bond linking "effects or incorporeal events" among themselves. And the virtual is a realm of effects separated from their causes: "effects in the causal sense, but also sonorous, optical, or linguistic 'effects'”, just like the cinematic special effects. For Deleuze, these special effects are "quasi-causes", which are "unreal and ghostly" causalities. They partake of only "extra-being”; they are "sterile, inefficacious, and on the surface of things". See Gilles Deleuze, The Logic of Sense, trans. by Mark Lester (New York: Columbia University Press, 1990), pp. 6-7, p. 33.
} 
is fictional or false” (2000, pp. 64-65).

In Out of this World, Peter Hallward deals with the Deleuzean dualism explicably. He first notes that "the actual is always constituted, while the virtual is wholly constituent”. He regards it as the key to understanding Deleuze's philosophy, for the virtual is always creative and the actual is always created. Virtual-creating is a pure form of creativity in and of itself. It should be viewed as a pure primordial energy, which is both the constituent force of its power to create, along with its inexhaustible need for transformation and change (2006, p. 37). Christopher Satoor adds a footnote to Hallward's words:

A creating is not just a novel concept; it is entirely new in itself and eternal. What makes creating new is precisely this immanent and internal spark that creates and manifests change and transformation. In reality, the actual creature is only a simulation of its "real" identity. The material self is only an optical illusion or effect of what is produced. It is only the virtual-creating that can produce the "new” or novel. (2017, pp. 30-31)

To sum up, the virtuality is in essence a creating power. Its actualization is an act of creating that will result in change and transformation. This is why the nature of virtuality is always fictional because what it has created is sure to be differentiated from the reality. On the other hand, the actuality, or the actual state of a creature, is nothing but an illusion because it is purely a production and creation, or to be more precise, a simulation of what the creature truly is ${ }^{8}$.

At this point, it's high time that I drew a conclusion from my discussion of Macherey and Deleuze. First of all, according to Deleuze, the unsaid or the narrative rupture is a possibility that should be explored, or a potentiality that can be tapped. By no means should it be viewed as a weakness or an error; instead, it is an alternative possible case scenario for the text. It is what the text could have been like. Now that the text has been written, it would seem that this potentiality will remain dormant and untapped. However, as far as readers are concerned, the unsaid can be said and will offer us an insightful reading of the text. Likewise, in postulating his virtual(ity)/actual(ity) dualism, Deleuze also regards the virtual(ity) as a potentiality. It is a dimension that hasn’t become an actuality. That is to say, as a potentiality may be tapped, the virtual can be actualized as well. As for how the virtual should get actualized, Maurice O’Sullivan observes, “The actualization of the virtual, on the contrary, always takes place by difference, divergence or differentiation” (2009, p. 212). By “differentiation”, Deleuze means "the production of newness", or multiplicities (2009, p. 166). In fact, this is what Deleuze terms "virtual-creating"; the virtual(ity) is essentially a form of creativity. As long as a virtuality is actualized, a transformation or a series of changes must arise, and something entirely new must be created readily ${ }^{9}$.

\footnotetext{
${ }^{8}$ In his paper, Satoor has clustered quite a few critical Deleuzean concepts in discussing Deleuze's virtual(ity)/actual(ity) couplet. For instance, he states, "Actualisation belongs to the virtual and the actualisation of a virtual singularity is constituted by the plane of immanence. This plane is where the creature is properly dissolved and annihilated". Also, Satoor quotes Hallward in "Deleuyze and the World Without Others", arguing that Deleuze encourages us to "de-straify" or "de-organize” ourselves, and dismantle the actual assemblage. The process is, according to Deleuze, is a line of flight. And the outcome is what Deleuze terms "the body without organs”. See Satoor, 2017, pp. 33, 35. Peter Hallward, “Deleuze and the World Without Others”, Philosophy Today, Vol. 41, No. 4 (1997), p. 534.

9 Moreover, O'Sullivan points out that the model can apply to our human body, "For Deleuze, the subject—or simply the human brain body configuration-is a subtraction from the plenitude of the world, a veritable centre of action/indetermination. Crucially, such a body can, via various technologies, open up further to the world —or actualize further virtualities via difference". Such a viewpoint can also relate to Spinoza, "For no one has thus far determined the power of the body, that is, no one has yet been taught by experience what the body can do merely by the laws of nature...” See O’Sullivan, 2009, p. 167. Baruch Spinoza, Ethics, trans. by A. Boyle (London: Everyman, 1989), p. 87.
} 
My argument above should shed light on the dialogical space between Macherey and Deleuze. In A Theory of Literary Production, Macherey discusses J. L. Borges this way:

The real narrative is then determined by the absence of all the other possible narratives from amongst which it could have been chosen: this absence hollows out the form of the book by putting it into endless conflict with itself. (1978, p. 256)

It's nearly as if Macherey is concurring with Deleuze on what the multiplicities the virtual(ity) represents ${ }^{10}$ : The narrative absence or the unsaid stands for infinite paths the author could have chosen, and these paths represent different possible developments of the text that simply contradict with what the text is like now. That is, whenever an author leaves something unsaid, (s)he is literally creating a repository of virtualities or potentialities, namely, factors that could have helped to shape the text differently. (It is usually at this point where readers or the author utters what the title of this paper reads, "It could have been said!”) Last but not least, as the virtuality can be actualized, the unsaid may be said. And in both the cases, the outcomes are the same: Something new or novel is created, or a text that is differently shaped is perceived. Thus, the dialogical space between Macherey and Deleuze is opened up.

\section{An Example: Marquis de Sade}

In The Object of Literature, Macherey has used Marquis de Sade as another instance. As we all know, de Sade's works aim to dismantle the existing society:

It [de Sade's work] describes the establishment of a society corresponding to literally extraordinary conditions. It exists outside the law, is completely cut off from real societies and their rules, and defies them by the very fact of it existence...This presupposes the fencing off of a perfectly enclosed place...Once all the bridges have been cut...passions establish a new order. Let our desires be our only laws. (1990, p. 149, italics mine)

Regarding de Sade's philosophy, Macherey adopts a perspective of "power”, or the politics of "domination" (p. 148). Power is responsible for the creation of law. "Law is conceived as being centered only upon itself, as coinciding absolutely with the collective order it organizes, and as referring to no external principle” (p. 152). This is how law serves its function of oppression and domination. It is a historical contradiction, and basically de Sade's whole politics is a reaction against it: De Sade wishes to establish a society that transcends these dominative rules and laws. Located in an enclosed space, this society can be protected from all the oppressions. Thus, a new order based on desire and passion may be created. Most of all, it "establishes the paradoxical figure of a law which overthrows all laws” (p. 151).

However, for Macherey this new order does not transcend social norms, as we generally would assume. Needless to say, it ought to be a narrative rupture in de Sade’s works. De Sade has left the following unsaid, "This society which challenges norms is, however, anything but a society without norms....” because paradoxically it reduplicates norms (p. 149):

\footnotetext{
${ }^{10}$ In Deleuze: The Clamor of Being, Alain Badiou critiques Deleuze's philosophy. He thinks that it is too abstract and centered on ascetic thinkers. He also points out that it is organized around a metaphysics of the one and contains the dispossession of the subject. Above all, a creative ascetic exercise is required in understanding the Deleuzean traditions. See Alain Badiou, Deleuze: The Clamor of Being (Minneapolis: University of Minnesota Press, 2004), p. 16.
} 
What is new about this order? What distinguishes it from the old order it has overthrown? The new element has nothing to do with the abolition of all laws. On the contrary, no society is better or more strictly ordered than a society ruled by desire. (p. 152)

Judging from how rigorously regulated of this society, Macherey argues that it is founded on a system integrating all most negative aspects of the law. Consequently, it does not subvert the law as it is expected to; instead, "it establishes a new relationship with the law" (p. 152). Above all, Macherey makes it a point that it is a relationship that is even more characteristic of domination (p. 153). ${ }^{11}$ That is to say, de Sade has absorbed the historical contradiction and reshaped it into the narrative rupture, which can be schematized as such:

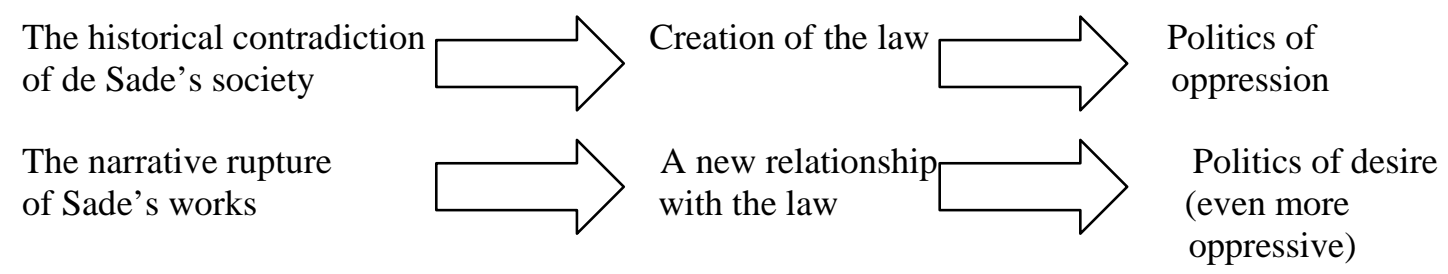

The core of this schema may be said to be this simple fact that is previously emphasized: The social contradiction remains unresolved in the text and winds up as the narrative rupture/unsaid. In "Literature as an Ideological Form”, Balibar and Macherey state, "Literature is not fiction...By a complex process, literature is the production of a certain reality, not indeed...an autonomous reality, but a material reality of a social effect...” (1995, p. 287). That is, they regard literature as a production of a material reality; a certain reality could be materially generated in a text. They choose the word "production" over "reflection" because literature is not a mirror-like reflection. Literature "translate(s)" reality (Macherey \& Lanser, 1976, p. 7) and its relationship with reality "is the development of a process of conflict within the reality itself" (p. 15). And all these are due to the fact that an author "always reveals or writes from a certain position" (Macherey, 1978, p. 195).

So far a Machereyan reading of de Sade has located the narrative rupture/unsaid; it has also helped us see the unresolved social contradiction embedded in de Sade's texts, which is also the origin of the narrative rupture/unsaid. To put it in a nutshell, the interrelationship between law, power/domination, and desire should be problematized. Or we can go a bit further and be more specific: Desire could be a lot more correlated with oppression than de Sade thinks. In a sense, Lacan has discovered it, so "in his psychoanalytic study of "desire", Lacan puts Sade and Kant together...His assigning Sade as the successor of Kant as well as the critical turning point of traditional ethics has led psychoanalysis, as a result, on the road to a subversion of ethics” (Shen, 2014, p. 130).

Before we go to Deleuze, we need to note that Macherey looks upon the theme as "a tool which no longer has its finished form....and must be made to meet new requirements" in commenting on Jules Verne A Theory of

\footnotetext{
${ }^{11}$ In Macherey’s opinion, in the old society there is an intermediary system between victims and executioners. However, the social utopia imagined by de Sade "brings victims and executioners face to face without any intermediaries, and forces the victims to suffer all the rigors of a power whose complete enjoyment is the preserve of their executioners. And the power of the executioners is all the more arbitrary in that it is supposedly absolute”. In other words, it is an extremely non-reciprocal relationship, in which all the possibilities of rebellion have been eliminated. From this perspective, Macherey regards de Sade's whole politics as "an answer to the following question: what happens when the people are prevented from rebelling because the law they obey coincides completely with the social order that oppresses them?” See Macherey, 1978, pp. 152-153.
} 
Literary Production (1978, p. 202). Macherey has basically informed us that the story theme is open for adjustment. So in the case of de Sade, it is how he thematicizes desire and oppression that has brought about the narrative rupture, where we shall find a hoarder of potentialities, namely, all the alternative enactments of the case scenarios of de Sade's texts. Of course, de Sade, who has already positioned himself in writing the texts, can't possibly rewrite these texts. However, as readers, we must ask this question all the time, "Could de Sade have thematicized desire and oppression differently? And if so, what would these texts be like?” We need to take notice of what Alfred North Whitehead has termed "eternal objects", which are "Pure Potentials" (1978, p. 22). Keith Robinson contends that Whitehead's so-called "eternal object” is synonymous with Deleuze's "virtual”. Most of all, "the potentiality of an eternal object is realized in a particular actual entity, it contributes to the definiteness of that actual entity” (2006, p. 23). So these potentialities are what de Sade could have done with the texts thematically, and they are also indicative of the alternative developments of the texts there might have been. If an author decides to pick up where de Sade has left off and write a sequel to his works one day, (s)he may very well repair this narrative rupture, say what de Sade can't say, and commence a process of actualizing a virtuality, as Deleuze would see!

\section{Conclusion}

Alan Sinfield in "Reading Critical Practice and Macherey” states, “All stories comprise within themselves the ghosts of the alternative stories they are trying to exclude” (2010, p. 1061). His so-called "the ghosts of the alternative stories" are Macherey’s "narrative ruptures” or "unsaid”. According to Macherey, they’re what the author can't say in the text because (s)he has chosen a position in viewing ideology. Above all, the unsaid or narrative ruptures are potentialities that exist in another dimension of the text, indicating the alternative developments of the text. It is at this point where we can discover the dialogical space between Macherey and Deleuze, because Deleuze asserts that virtuality, unlike actuality, is also a potentiality in another dimension. Once actualized, it will transform into something new. Hence, we can conclude that Macherey's unsaid or narrative rupture is Deleuze's virtuality. It is a potentiality in the text that conveys a key message: If tapped, it will result in a makeover of the text!

\section{References}

Badiou, A. (2004). Deleuze: The clamor of being. Minneapolis: University of Minnesota Press.

Bakhtin, M. (1976). Problems of Dostoevsky's poetics. (R. W. Rostel, Trans.). Michigan: Ardis/Ann Arbor.

Balibar, E., \& Macherey, P. (1995). Literature as an ideological form. In T. Eagleton and D. Milne (Eds.), Marxist literary theory: A reader (pp. 276-295). Chichester: Wiley-Blackwell.

Belsey, C. (1980). Critical practice. New York: Menthuen \& Co. Ltd.

Bennett, A., \& Royle, N. (1999). Introduction to literature, criticism and theory. Hemel Hempstead: Prentice Hall Europe.

Bergson, H. (1991). Matter and memory. (N. M. Paul \& W. Scott Palmer, Trans.). New York: Zone Books.

Boeckmann, S. L. V. (1998). Marxism, morality, and the politics of desire: Utopianism in Fredric Jameson’s The political unconscious. Utopian Studies, 9(2), 31-50.

Burke, K. (1973). The philosophy of literary form. Princeton: University of California Press.

Deleuze, G. (1983). Nietzsche and philosophy. (H. Tomlinson, Trans.). New York: Columbia University Press.

Deleuze, G. (1989). Cinema 2: The time image. (H. Tomlinson \& R. Galeta, Trans.). London: Continuum Press.

Deleuze, G. (1990). The logic of sense. (M. Lester, Trans.). New York: Columbia University Press.

Deleuze, G. (1991). Bergsonism. (H. Tomlinson \& B. Habberjam, Trans.). New York: Zone Books.

Deleuze, G. (1995). Difference and repetition. (P. Patton, Trans.). New York: Columbia University Press. 
Deleuze, G. (2006). Response to a question on the subject. In D. Lapoujade (Ed.), Two regimes of madness: Texts and interviews 1975-1995 (pp. 143-152). (A. Hodges \& M. Taormina, Trans.). New York: Semiotext.

Deleuze, G., \& Guattari, F. (1994). What is philosophy? (H. Tomlinson \& G. Burchell, Trans.). New York: Columbia University Press.

Dowling, W. C. (1984). Jameson, Althusser, Marx. London: Menthuen \& Co. Ltd.

Eagleton, T. (1976). Criticism and ideology: A study in Marxist literary theory. London: Verso.

Gibson, A. (1996). Towards a postmodern theory of narrative. Edinburgh: Edinburgh University Press.

Hallward, P. (1997). Deleuze and the world without others. Philosophy Today, 41(4), 530-540.

Hallward, P. (2006). Out of this world: Deleuze and the philosophy of creation. London: Verso.

Huang, B. B. F. (2018). “Some things must be left unsaid!”-On how Macherey is dialogically engaged with post-Marxism. Journal of Literature and Art Studies, 8(3), 487-508.

Jameson, F. (1981). The political unconscious: Narrative as a socially symbolic act. Cambridge: Cambridge University Press.

Jones, P. (2003). Raymond Williams' sociology of culture: A critical reconstruction. London: Macmillion.

Kurzweil, E. (1980). The age of structuralism: Levi-Strauss to Foucault. New York: Columbia University Press.

Lawlor, L. (August 2000). A nearly total affinity: The Deleuzian virtual image versus the Derridean trace. Journal of the Theoretical Humanities, 5(2), 59-71.

Macherey, P. (1978). A theory of literary production. (G. Wall, Trans.). London: Routledge \& Kegan Paul.

Macherey, P. (1990). The object of literature. (D. Macey, Trans.). Cambridge: Cambridge University Press.

Macherey, P., \& Lanser, S. S. (1976). The problem of reflection. Substance, 5(15), 6-20.

Mao, T.-T. (1971). Selected readings from the works of Mao, Tse-Tung (A). Peking: Foreign Language Press.

O’Sullivan, S. (July 2009). The strange temporality of the subject: Badiou and Deleuze between the finite and infinite. International Journal of Critical Psychology, 27(1), 155-171.

Pearson, K. A. (1997). Deleuze outside/outside Deleuze. In A. Pearson (Ed.), Deleuze and philosophy: The difference engineer (pp. 1-22). London: Routledge.

Pearson, K. A. (2005). The reality of the virtual: Bergson and Deleuze. MLN, 120, 1112-1127.

Robinson, K. (2006). The new Whitehead? An ontology of the virtual in Whitehead's metaphysics. Symposium, 10, 69-80.

Russo, J. (2008). The self as resolution: Heidegger, Derrida and the intimacy of the question of the meaning of being. Research in Phenomenology, 38(1), 90-110.

Satoor, C. (2017). A “part” of the world: Deleuze and the logic of creation. Deleuze Studies, 11(1), 25-47.

Shaviro, S. (2009). Without criteria: Kant, Whitehead, Deleuze, and aesthetics. Cambridge, Massachusetts: The MIT Press.

Shen, C.-C. (2014). Sade and psychoanalysis. Chung Wai Literary Quarterly, 43(2), 129-151.

Sinfield, A. (December 2010). Reading Critical practice and Macherey. Textual Practice, 24(6), 1059-1072.

Smith, D. W. (Spring 2009). Deleuze's concept of the virtual and the critique of the virtual. Journal of Philosophy: A Cross-Disciplinary Inquiry, 4(9), 34-43.

Spinoza, B. (1989). Ethic. (A. Boyle, Trans.). London: Everyman.

Whitehead, A. N. (1978). Process and reality. New York: The Free Press.

Williams, R. (1989). What I came to say. F. Mullhern, (Ed.). London: Hutchinson Radius.

Wolff, R. D. (April 2005). Ideological state apparatuses, consumerism, and U. S. capitalism: Lessons for the left. Rethinking Marxism, 17(2), 223-235. 